\title{
Impact of Nutritional Counselling on Nutritional Status of Postmenopausal Women
}

\author{
Gurpreet Kaur, Paramjit Chawla \\ Department of Food and Nutrition, College of Home Science, Punjab Agricultural University, Ludhiana, India \\ Email: gkaur0077@gmail.com
}

Received 30 January 2015; accepted 20 March 2015; published 24 March 2015

Copyright (C) 2015 by authors and Scientific Research Publishing Inc.

This work is licensed under the Creative Commons Attribution International License (CC BY). http://creativecommons.org/licenses/by/4.0/

(c) (i) Open Access

\section{Abstract}

The aim of the study was to assess the impact of nutrition counselling on food intake and anthropometric measurements in postmenopausal women. Sixty postmenopausal women were selected from two villages of Sangrur district and were divided into two groups-Group I (Control) and Group II (Experimental) containing 30 subjects each. Subjects of Group II were imparted nutrition counselling (NC) regarding benefits of Aloe vera and its use in diet in individual and group contacts once in a week, for a period of three months. Aloe vera plants were also distributed to be used in their diets. Dietary intake of subjects for 3 consecutive days by $24 \mathrm{hr}$ recall method was recorded before and after nutrition counselling. The average daily nutrient intake of diets was calculated by using Diet Cal. Anthropometric parameters were calculated before and after counselling. Dietary survey revealed that intake of cereals, fats/oil and sugar/jaggery decreased significantly $(p \leq 0.05)$ whereas intake of green leafy vegetable, other vegetables and fruits increase significantly $(p \leq$ 0.01) after counselling. A significant decrease in energy, carbohydrate, fat and significant increase intake in iron, calcium, potassium, Vitamin $C$ and $\beta$-carotene content was observed. A significant reduction was observed for weight, body mass index (BMI), mid upper arm circumference (MUAC), triceps skinfold thickness (TSFT) and waist hip ratio (WHR) by $4.9 \%, 3.98 \%, 2.9 \%$ and $2.17 \%$ respectively, while random blood sugar (RBS), systolic blood pressure (SBP) and diastolic blood pressure (DBP) decreased by $25.21 \%, 13.74 \%$ and $8.03 \%$ after counselling. After nutrition counselling subjects adopted good nutritional practices and use of Aloe vera leaves in diets which improved their health status of postmenopausal women.

\section{Keywords}

Aloe vera Leaves, Anthropometric Measurements, Nutrient Intake, Nutrition Counselling 


\section{Introduction}

The menopause is a particularly important time in a woman's life. It is a time of adaptation and transition to new biological situation which involves loss of the reproductive function. It is an aspect of human ageing and a useful predictive risk marker of a variety of aging - related diseases and health problems. Several biological and psychological changes take place during this phase. Menopause may be associated with vasometor symptoms, bone loss, urogenital atrophy, urinary tract infections and incontinence, increased cardiovascular risk, somatic symptoms, sexual dysfunction and loss of skin elasticity, which may have a significant negative impact on the overall quality of life for a substantial number of women [1]. Most women experience menopause between 40 and 58 years of age, the median age being 51 years. Typical symptoms at the time of menopause lasting 4 - 5 years are hot flushes, night sweats, vaginal dryness and sleep disturbances [2]. Medical opinion has always projected menopause as malady because of its association with a variety of acute and chronical conditions, both physical and psychological. Following the menopause, the effects of urogenital ageing are commonly apparent with declining levels of estrogen producing atrophic changes [3].

Aloe vera has marvellous medicinal properties. Scientists have discovered over 150 nutritional ingredients in Aloe vera. There seems to be no single magic ingredient. They all work together in a synergetic way to create healing and health giving benefits. The ten main areas of chemical constituents of Aloe vera include: amino acids, anthraquinones, enzymes, minerals, vitamins, lignins, monosaccharide, salicyclic acid, Saponins and phytosterols [4]. Vitamin C and Vitamin E are important antioxidant agents. Aloe vera exerts antioxidative effects by increasing the bioavailability of Vitamins $\mathrm{C}$ and $\mathrm{E}$ [5]. Aloe vera has very good nutritional composition. It contains 20 of the 22 Amino acids required for good nutrition. Aloe has shown to contain 13 of the 17 minerals required in the body, namely, calcium, potassium, phosphorus, sodium, chlorine, aluminium, magnesium, manganese, selenium, silicon, zinc and cobalt. Other than these minerals, vitamins like vit. $B_{1}, B_{2}, B_{3}$, choline, folic acid, vit. $C$ and carotene are also present in Aloe [6]. The use of neutraceuticals is new trend and plants still present a large source of natural antioxidants that may serve as leads for the development of antioxidant supplement. Aloe vera (Aloe Barbadensis Miller) is a species of Aloe. Among its many beneficial medicinal activities, Aloe vera inner leaf gel has potent antioxidant activities. It inhibits the chemical reactions through which oxidative molecules cause damage [7] [8].

Nutrition counselling aims at importance of balance diet and healthy eating habits for better management of symptoms, improvement of health and nutritional status, thus reducing potential for complications, promoting path way through physical and psychological well being and encouraging healthy eating habits during post menopause. In Punjab only few studies have been conducted relating to nutritional and heath status of postmenopausal women and effect of Aloe vera in daily use. The present study has been designed to study the impact of nutrition counselling regarding use of Aloe vera products on health status of postmenopausal women.

\section{Materials and Methods}

\subsection{Selection of Aloe vera Leaves}

Samples of Aloe vera (Aloe Barbadensis Miller) plant free from blemishes and damage were procured from Department of Agronomy, Punjab Agricultural University Ludhiana.

\subsection{Selection of Subjects}

Sixty postmenopausal women were selected from two villages Kasba Bhural and Dasounda Singh Wala, District Sangrur, Punjab. The criteria used for the selection of the subjects were as follows:

1) Female who were not having their menstrual periods from 1 - 3 years.

2) Aged between 50 - 60 years.

3) Free from serious complications.

Selected subjects were divided in to two groups-Group I (Control) and Group II (Experimental) containing 30 subjects each. Nutrition information was imparted to the selected subjects of Group II regarding benefits of Aloe vera, products of Aloe vera and their use in diet in individual and group contacts once in a week, for a period of three months. Nutrition counselling was not given to the subjects of Group I. Nutrition counselling was given through information education (IEC) material, booklet containing all the information regarding health benefits of Aloe vera and its use in different recipes. Demonstrations of different recipes incorporating Aloe vera 
were conducted. The subjects of Group II (experimental) were provided Aloe vera plant to be used in their diet.

\subsection{Nutritional Assessment}

Dietary intake of subjects of Group I and Group II for three consecutive days by $24 \mathrm{hr}$ recall method was recorded before and after counselling. The average daily nutrient intake of diets was calculated by using Indian Nutritional Software (Dietcal). Various anthropometric parameters viz. height, weight, Body Mass Index (BMI), Mid Upper Arm Circumference (MUAC), Triceps Skin Fold Thickness (TSFT), Waist Hip Ratio (WHR) were recorded before and after counselling using standard method given by Jelliffe [9].

\subsection{Biochemical Assessment}

Random Blood Sugar (RBS) levels were estimated by finger prick method using Glucometer. Systolic (SBP) and Diastolic Blood Pressure (DBP) was also recorded by using a sphygmomanometer given by Maclead [10] before and after nutrition counselling.

\subsection{Statistical Analysis}

Data were statistically analyzed by student's t-test and paired t-test were used to test the significant $(p<0.05, p$ $<0.01$ ) differences between variables.

\section{Results and Discussion}

\subsection{Food and Nutrient Intake of the Subjects}

Table 1 depicted that the mean intake of green leafy vegetables, roots and tubers, other vegetables and fruits was inadequate, whereas pulses, milk and milk products, fats and oils and sugar and jaggery was more than suggested intake given by ICMR [11]. Data regarding daily food intake of the subjects revealed decrease in intake of cereals from 280.23 to $244.97 \mathrm{~g}$ in Group II (experimental) after counselling while increase in intake of pulses from 56.9 to $60.1 \mathrm{~g}$. Daily intake of other vegetables and milk and milk products was $75.5 \mathrm{~g}$ and $409 \mathrm{ml}$ respectively before counselling which increased significantly $(p \leq 0.01)$ to 82.5 and $434.2 \mathrm{ml}$ after NC. A significant increase was observed in consumption of fruits from 85.91 to $92.17 \mathrm{~g}$ after NC. Daily intake of fats/oils and sugar/jaggery decreased significantly $(p \leq 0.05)$ from $31.47 \pm 1.84$ and $36.7 \pm 1.16$ to $24.2 \pm 1.09$, $33.9 \pm 0.37$ in subjects of experimental group after counselling. The survey data of the previous study also revealed that a decrease in cereal consumption from $337.9 \mathrm{~g}$ to $326.2 \mathrm{~g}$ after nutrition counselling [12].

Nutrient intake of subjects in Table 2 as suggested by Ghafoorunissa and Krishnaswamy [13] revealed that mean daily intake of energy was $2191 \pm 12.86,2200 \pm 13.19 \mathrm{Kcal}$ and $2184 \pm 12.30,1774 \pm 12.73$ Kcal before and after NC in subjects of Group I and Group II respectively. Likewise, decreased intake of carbohydrate and protein was observed in experimental group from $350 \pm 16.07$ to $267.8 \pm 11.73 \mathrm{~g}$ and $64.92 \pm 0.89 \mathrm{~g}$ to $60.17 \pm$ $0.43 \mathrm{~g}$ after NC. The mean daily intake of fat in Group I and Group II were $63.12 \pm 0.55,59.13 \pm 0.70 \mathrm{~g}$ and $63.99 \pm 0.73,47.2 \pm 0.46 \mathrm{~g}$ before and after counselling respectively. The mean daily intake of dietary fibre was $10.49 \pm 0.11,9.13 \pm 0.13 \mathrm{~g}$ and $11.03 \pm 0.17,17.31 \pm 0.33 \mathrm{~g}$ in Group I and Group II respectively. There was a significant increase in intake of fibre in subjects of Group II after counselling. The mean intake of total fats by postmenopausal Punjabi women was $60.76 \pm 0.57 \mathrm{~g}$ [14]. In line, the mean intake of fibre in vegetarian postmenopausal women was $12.4 \mathrm{~g}$ [15].

Persual of the data indicated that intake of fibre was less than the RDA where as intake of energy, protein, total fat was more than RDA. Mean daily intake of energy, carbohydrates, protein and total fat decreased after the nutrition counselling which may be due to decreased consumption of cereals, pulses, roots and tuber, fats/oil and sugar/jaggery. Whereas mean daily intake of dietary fibre increased after the NC which may be due to increase in consumption of Aloe vera, green leafy vegetables, other vegetables, roots and tubers and fruits.

The data on mean daily intake of vitamins and minerals as given by ICMR [16] clearly indicated that the mean daily intake of Vitamin C was $26.97 \pm 0.35 \mathrm{mg}$ which significantly $(p \leq 0.01)$ increased to $31.17 \pm 0.71$ $\mathrm{mg} /$ day in subjects of Group II (experimental) due to consumption of Aloe vera leaves in daily diet. $\beta$-carotene was found to be $2424 \pm 91.76 \mu \mathrm{g} /$ day before counselling which was $3274 \pm 99.71 \mu \mathrm{g} / \mathrm{day}$ after counselling in Group II. There was significant increase in calcium, phosphorus, iron and potassium and decrease in sodium after NC. The mean daily intake of iron and calcium were $14.88 \pm 0.03 \mathrm{mg}$ and $545.75 \pm 4.78 \mathrm{mg}$ before nutrition 
Table 1. Daily food intake of the subjects before and after nutrition counselling.

\begin{tabular}{|c|c|c|c|}
\hline Food Groups & $\begin{array}{c}\text { Group I (Control) } \\
\quad(n=30)\end{array}$ & $\begin{array}{l}\text { Group II (Experimental) } \\
\qquad(\mathbf{n}=\mathbf{3 0})\end{array}$ & Suggested Intake \\
\hline \multicolumn{4}{|l|}{ Cereals (g) } \\
\hline Before & $269.07 \pm 7.79$ & $280.23 \pm 7.45$ & \multirow{3}{*}{270} \\
\hline After & $268.33 \pm 8.24$ & $244.97 \pm 6.58$ & \\
\hline t Value & $0.82^{\mathrm{NS}}$ & $5.86^{* *}$ & \\
\hline \multicolumn{4}{|c|}{ Pulses and Legumes (g) } \\
\hline Before & $57.9 \pm 1.89$ & $56.9 \pm 1.85$ & \multirow{3}{*}{60} \\
\hline After & $58.1 \pm 1.86$ & $60.1 \pm 1.64$ & \\
\hline t Value & $1.20^{\mathrm{NS}}$ & $3.88^{* *}$ & \\
\hline \multicolumn{4}{|c|}{ Green Leafy Vegetables (g) } \\
\hline Before & $52.57 \pm 1.25$ & $53.8 \pm 1.30$ & \multirow{3}{*}{100} \\
\hline After & $53.13 \pm 0.03$ & $59.83 \pm 1.15$ & \\
\hline t Value & $1.94^{\mathrm{NS}}$ & $6.94^{* *}$ & \\
\hline \multicolumn{4}{|c|}{ Other Vegetable (g) } \\
\hline Before & $82.7 \pm 0.68$ & $75.5 \pm 0.61$ & \multirow{3}{*}{200} \\
\hline After & $83.03 \pm 0.11$ & $82.5 \pm 0.68$ & \\
\hline t Value & $1.43^{\mathrm{NS}}$ & $8.13^{* *}$ & \\
\hline \multicolumn{4}{|l|}{ Roots/Tubers (g) } \\
\hline Before & $84.37 \pm 0.79$ & $82.23 \pm 1.32$ & \multirow{3}{*}{200} \\
\hline After & $84.43 \pm 0.63$ & $87.03 \pm 0.88$ & \\
\hline t Value & $0.73^{\mathrm{NS}}$ & $5.52^{* *}$ & \\
\hline \multicolumn{4}{|l|}{ Fruits (g) } \\
\hline Before & $87.08 \pm 0.75$ & $85.91 \pm 1.99$ & \multirow{3}{*}{100} \\
\hline After & $87.58 \pm 0.63$ & $92.17 \pm 1.11$ & \\
\hline t Value & $1.33^{\mathrm{NS}}$ & $3.76^{* * *}$ & \\
\hline \multicolumn{4}{|c|}{ Milk and Milk Products (ml) } \\
\hline Before & $408.3 \pm 1.48$ & $409 \pm 3.47$ & \multirow{3}{*}{300} \\
\hline After & $410.61 \pm 0.99$ & $434.2 \pm 1.58$ & \\
\hline t Value & $1.51^{\mathrm{NS}}$ & $7.51^{* *}$ & \\
\hline \multicolumn{4}{|l|}{ Fats/Oil (g) } \\
\hline Before & $31.8 \pm 1.71$ & $31.47 \pm 1.84$ & \multirow{3}{*}{20} \\
\hline After & $30.13 \pm 1.75$ & $24.2 \pm 1.09$ & \\
\hline t Value & $1.90^{\mathrm{NS}}$ & $4.67^{* *}$ & \\
\hline \multicolumn{4}{|l|}{ Sugar/Jaggery (g) } \\
\hline Before & $37.3 \pm 0.51$ & $36.7 \pm 1.16$ & \multirow{3}{*}{20} \\
\hline After & $36.8 \pm 0.43$ & $33.9 \pm 0.37$ & \\
\hline t Value & $1.34^{\mathrm{NS}}$ & $2.59^{*}$ & \\
\hline
\end{tabular}

Values presents mean $\pm \mathrm{SE} ;{ }^{* *}$ Significant at 1 percent level of significance; NS: Non-significant.

counselling which increased to $17.29 \pm 0.08$ and $660.77 \pm 5.52 \mathrm{mg}$ in subjects of experimental group respectively. In line, another study reported low intake of iron by Punjabi women, i.e. $17 \mathrm{mg}$ [17]. The mean daily intake of phosphorus was $563.43 \pm 5.03 \mathrm{mg}$ and $621.43 \pm 5.74 \mathrm{mg}$ before and after nutrition counselling in the subjects of Group II respectively. Daily mean intake of potassium was $462.25 \pm 4.68 \mathrm{mg}$ and $660.02 \pm 4.96 \mathrm{mg}$ before and after NC by the subjects of Group II. The mean daily intake of sodium was $297.7 \pm 12.8 \mathrm{mg}$ before counselling which decreased to $261.1 \pm 11.31 \mathrm{mg}$ after nutrition counselling in subjects of experimental group.

\subsection{Anthropometric Measurements}

The anthropometric profile of the selected subject is presented in Table 3. The mean height of the subjects of Group I (control) and Group II (experimental) was $159 \pm 0.63 \mathrm{~cm}$ and $158 \pm 0.63 \mathrm{~cm}$ respectively. Mean height of postmenopausal women to be $157 \mathrm{~cm}$ [18]. Mean weight of the subjects were $66.76 \pm 0.93$ and $68.71 \pm 0.93 \mathrm{~kg}$ before NC in Group I and Group II, respectively which was more than the standard value given by ICMR [19] 
Table 2. Nutrient intake of postmenopausal women before and after nutrition counselling.

\begin{tabular}{|c|c|c|c|c|c|c|}
\hline \multirow{2}{*}{ Nutrients } & \multicolumn{2}{|c|}{ Group I (Control) } & \multicolumn{2}{|c|}{ Group II (Experimental) } & \multirow{2}{*}{ t Value } & \multirow{2}{*}{ RDA } \\
\hline & Before & After & Before & After & & \\
\hline Energy (Kcal) & $2191 \pm 12.86$ & $2184 \pm 12.30$ & $2200 \pm 13.19$ & $1774 \pm 12.73$ & $4.45^{* *}$ & $1800-2400$ \\
\hline Carbohydrate (g) & $338 \pm 15.89$ & $337 \pm 15.07$ & $350 \pm 16.07$ & $267.8 \pm 11.73$ & $4.75^{* *}$ & $300-340$ \\
\hline Protein (g) & $64.93 \pm 0.71$ & $65 \pm 0.92$ & $64.92 \pm 0.89$ & $60.17 \pm 0.43$ & $4.69^{* *}$ & $50-60$ \\
\hline Total Fat (g) & $63.12 \pm 0.55$ & $63.99 \pm 0.73$ & $59.13 \pm 0.70$ & $47.2 \pm 0.46$ & $3.08^{* *}$ & $40-60$ \\
\hline Dietary Fibre (g) & $10.49 \pm 0.11$ & $11.03 \pm 0.17$ & $9.13 \pm 0.13$ & $17.31 \pm 0.33$ & $6.51^{* *}$ & 40 \\
\hline Vitamin C (mg) & $28.30 \pm 0.40$ & $29.01 \pm 0.54$ & $26.97 \pm 0.35$ & $31.17 \pm 0.71$ & $3.72^{* *}$ & 40 \\
\hline$\beta$ Carotene $(\mu \mathrm{g})$ & $2692 \pm 93.52$ & $2701 \pm 94.3$ & $2424 \pm 91.76$ & $3274 \pm 99.71$ & $2.04^{*}$ & 4800 \\
\hline Iron (mg) & $15.00 \pm 0.04$ & $15.41 \pm 0.10$ & $14.88 \pm 0.03$ & $17.29 \pm 0.08$ & $3.76^{* *}$ & 21 \\
\hline Calcium (mg) & $411.28 \pm 4.43$ & $394.17 \pm 4.01$ & $545.75 \pm 4.78$ & $660.77 \pm 5.52$ & $2.76^{* *}$ & 800 \\
\hline Phosphorus (mg) & $427.21 \pm 4.71$ & $456 \pm 4.84$ & $563.43 \pm 5.03$ & $621.43 \pm 5.74$ & $2.79^{* *}$ & 800 \\
\hline Sodium (mg) & $294.2 \pm 12.71$ & $296.6 \pm 12.91$ & $297.7 \pm 12.8$ & $261.1 \pm 11.31$ & $1.77^{*}$ & 1902 \\
\hline Potassium (mg) & $419.56 \pm 4.81$ & $412 \pm 3.94$ & $462.25 \pm 4.68$ & $660.02 \pm 4.96$ & $5.71^{* *}$ & 1000 \\
\hline
\end{tabular}

Values are mean $\pm \mathrm{SE} ;{ }^{* *}$ Significant at $1 \%$ level of significance; ${ }^{*}$ Significant at $5 \%$ level of significance; NS: Non-significant.

Table 3. Anthropometric parameters of subjects before and after nutrition counselling.

\begin{tabular}{|c|c|c|c|c|c|}
\hline Parameters & Before & After & \% Change & t Value & Standard Range \\
\hline \multicolumn{6}{|l|}{ Height (cm) } \\
\hline Group I (Control) & $159 \pm 0.63$ & $159 \pm 0.63$ & - & NS & - \\
\hline Group II (Experimental) & $158 \pm 0.63$ & $158 \pm 0.63$ & - & NS & - \\
\hline \multicolumn{6}{|l|}{ Weight (Kg) } \\
\hline Group I & $66.76 \pm 0.93$ & $67.01 \pm 0.93$ & 0.37 & NS & 61 \\
\hline Group II & $68.71 \pm 0.93$ & $64.92 \pm 0.93$ & 5.5 & $3.64^{* *}$ & \\
\hline \multicolumn{6}{|l|}{ BMI $\left(\mathrm{Kg} / \mathbf{m}^{2}\right)$} \\
\hline Group I & $28.47 \pm 0.83$ & $28.44 \pm 0.82$ & 0.1 & NS & $18.5-24.99$ \\
\hline Group II & $28.28 \pm 1.01$ & $26.87 \pm 0.94$ & 4.9 & $9.01^{* *}$ & \\
\hline \multicolumn{6}{|l|}{ MUAC (cm) } \\
\hline Group I & $31.74 \pm 0.77$ & $31.74 \pm 0.77$ & - & NS & 29.3 \\
\hline Group II & $31.40 \pm 0.76$ & $30.15 \pm 0.68$ & 3.98 & $4.82^{* *}$ & \\
\hline \multicolumn{6}{|l|}{ TSFT (mm) } \\
\hline Group I & $21 \pm 0.12$ & $20.97 \pm 0.12$ & 0.14 & NS & 16.5 \\
\hline Group II & $18.1 \pm 0.07$ & $17.57 \pm 0.41$ & 2.9 & $6.19^{* *}$ & \\
\hline \multicolumn{6}{|l|}{ WHR } \\
\hline Group I & $0.91 \pm 0.12$ & $0.91 \pm 0.12$ & - & NS & $<0.80$ \\
\hline Group II & $0.92 \pm 0.07$ & $0.90 \pm 0.07$ & 2.17 & $11.8^{* *}$ & \\
\hline
\end{tabular}

Values are mean $\pm \mathrm{SE} ;{ }^{* *}$ Significant at $1 \%$ level of significance; NS: Non-significant. 
and it decreased by 5.5 percent in Group II after counselling which may be due to decrease in daily intake of cereals, fats/oils and sugar/jaggery. After NC and Aloe vera powder (100 mg/day) supplementation weight of subjects suffering from NIDDM significantly $(p \leq 0.01$ ) reduced to $73.10 \mathrm{Kg}$ from $75.20 \mathrm{Kg}$ [20].

The mean BMI before counselling in the subjects of Group I and Group II was $28.47 \pm 0.83,28.28 \pm 1.01$ $\mathrm{Kg} / \mathrm{m}^{2}$. It was observed that BMI so obtained was higher in Group I and Group II as compared to standard range given by WHO [21]. A highly significant $(p \leq 0.01)$ decrease was observed in experimental group after NC by 4.9 percent. In line, another study reported the mean BMI of women from Bangalore in the age group of 45 - 50 years as 27.8 to $28.9 \mathrm{~kg} / \mathrm{m}^{2}$ [22]. In NIDDM subjects before counselling BMI was $26.11 \mathrm{Kg} / \mathrm{m}^{2}$ which reduced to $25.38 \mathrm{~kg} / \mathrm{m}^{2}$ after NC and Aloe vera powder (100 mg/day) supplementation and significant $(p \leq 0.01)$ reduction was observed [20].

The mean values of MUAC of the subjects was $31.74 \pm 0.77,31.40 \pm 0.76 \mathrm{~cm}$ before nutrition counselling in Group I (control) and Group II (experimental) respectively. The observed values of MUAC in subjects of both the groups were higher than the standard value [9]. A significant $(p \leq 0.01)$ reduction in MUAC was observed in Group II (3.98\%) which may be due to consumption of Aloe vera leading to decrease in weight. Mean MUAC of postmenopausal women as $31.85 \pm 1.11 \mathrm{~cm}$ which is near to the finding of present study [14]. Mean values of TSFT were $18.1 \pm 0.07 \mathrm{~mm}$ which decreased to $17.57 \pm 0.41$ in Group II after NC which was higher than the standard value i.e. 16.5 [9]. A significant $(p \leq 0.01)$ decrease in TSFT values was observed in Group II was 2.9 percent. Mean WHR of the subjects before and after the counselling was $0.91 \pm 0.12,0.92 \pm 0.14$ and $0.91 \pm$ 0.12, $0.90 \pm 0.07$ in Group I and Group II respectively which was higher than the standard value, i.e. $<0.80$ given by Ghafoorunissa and Krishnaswamy [23]. The data revealed that the waist hip ratio of postmenopausal women was 0.95 [15].

\subsection{Random Blood Sugar (RBS) Level of the Subjects}

The present study in Table 4 [24] revealed that the mean values of RBS were $240.63 \pm 11.54,241.4 \pm 14.40$ $\mathrm{mg} / \mathrm{dl}$ and $239.57 \pm 11.46,180.53 \pm 8.05 \mathrm{mg} / \mathrm{dl}$ in Group I (control) and Group II (experimental) before and after nutrition counselling respectively. A significant $(p \leq 0.01)$ decrease in RBS level was 25.21 percent. After nutrition intervention, i.e. Aloe vera powder supplementation (100 mg/day) in NIDDM subjects the values of blood glucose level of subjects reduced to $153.37 \mathrm{mg} / \mathrm{dl}$ from $185.07 \mathrm{mg} / \mathrm{dl}$ at baseline [20]. Administration of the five phytosterols from Aloe vera namely/lophenol, 24-methyl-lophenol, 24-ethyl-lophenol, cycloartanol and 24-methylene-cycloratanol to severe type 2 diabetic mice for 28 days decreased the fasting blood glucose levels by $64 \%, 28 \%, 47 \%, 51 \%$ and $55 \%$ respectively [25].

\subsection{Blood Pressure Level of the Subjects}

The mean value for systolic blood pressure in Table 5 [26] were $132 \pm 4.56,143.38 \pm 5.08 \mathrm{~mm} \mathrm{Hg}$ and $132 \pm$ 5.56, $123.67 \pm 1.95 \mathrm{~mm} \mathrm{Hg}$ in the subjects of Group I and Group II before and after NC respectively. A significant $(p \leq 0.01)$ decrease was observed in Group II. The mean values of diastolic pressure were $90.66 \pm 2.63$, $95.33 \pm 3.06 \mathrm{~mm} / \mathrm{Hg}$ and $90.00 \pm 2.44,87.67 \pm 1.49 \mathrm{mmHg}$ in Group I and Group II before and after counselling respectively. A significant $(p \leq 0.01)$ decrease was observed in Group II. The mean initial systolic and diastolic blood pressure of the subjects was 137.63 and $86.03 \mathrm{~mm} \mathrm{Hg}$. After three months of Aloe vera supplementation (100 mg/day) the value of systolic and diastolic blood pressure of the subjects was 131.65 and $83.13 \mathrm{~mm} \mathrm{Hg}$. A

Table 4. Random blood sugar level of subjects before and after nutrition counselling.

\begin{tabular}{cccc}
\hline $\begin{array}{c}\text { Random Blood Sugar Level } \\
(\mathbf{m g} / \mathbf{d l})\end{array}$ & $\begin{array}{c}\text { Group I (Control) } \\
(\mathbf{n}=\mathbf{3 0})\end{array}$ & $\begin{array}{c}\text { Group II (Experimental) } \\
(\mathbf{n}=\mathbf{3 0})\end{array}$ & Standard Range \\
\hline Before & $240.63 \pm 11.54$ & $241.4 \pm 14.40$ & \\
After & $239.57 \pm 11.46$ & $180.53 \pm 8.05$ & $140-200 \mathrm{mg} / \mathrm{dl}$ \\
\% Change & 0.44 & 25.21 & \\
t Value & NS & $5.06^{* *}$ & \\
\hline
\end{tabular}

Value represents Mean $\pm \mathrm{SE} ;{ }^{* *}$ Significance at $1 \%$ level of significance; NS: Non-significant. 
Table 5. Blood pressure of the subjects before and after nutrition counselling.

\begin{tabular}{cccc}
\hline $\begin{array}{c}\text { Blood Pressure } \\
(\mathbf{m m} / \mathbf{H g})\end{array}$ & $\begin{array}{c}\text { Group I (Control) } \\
(\mathbf{n}=\mathbf{3 0})\end{array}$ & $\begin{array}{c}\text { Group II (Experimental) } \\
(\mathbf{n}=\mathbf{3 0})\end{array}$ & $\begin{array}{c}\text { Standard Range } \\
\text { Systolic Bp (mm Hg) }\end{array}$ \\
Before & $132 \pm 4.56$ & $143.38 \pm 5.08$ & \\
After & $132 \pm 4.56$ & $123.67 \pm 1.95$ & \\
\% Change & 0 & 13.74 & \\
t Value & NS & $4.91^{* *}$ & \\
Diastolic Bp (mm Hg) & & & \\
Before & $90.66 \pm 2.63$ & $95.33 \pm 3.06$ & \\
After & $90.00 \pm 2.44$ & $87.67 \pm 1.49$ & \\
\% Change & 0.72 & 8.03 & \\
t Value & NS & $2.99^{* *}$ & \\
\hline
\end{tabular}

Mean values $\pm \mathrm{SE} ;{ }^{* *}$ Significance at $1 \%$.

significant $(p \leq 0.01)$ reduction in blood pressure of the subjects of Group II after three months of counselling and Aloe vera supplementation [20].

\section{Conclusion}

From the above results it may be concluded that mean daily intake of green leafy vegetables, roots and tubers, other vegetables were inadequate where as cereals, milk and milk products, fats and oils were more than the suggested intake which decreased after counselling. A significant decrease in intake of energy, carbohydrate, fat and significant increase in intake of fibre was observed in experimental group. A significant decrease in weight, BMI, MUAC, TSFT and WHR in Group II was observed after counselling and due to decreased consumption of cereals, fats/oil and sugar/jaggery. A significant reduction was observed in RBS, SBP and DBP after counselling and may also due to consumption of Aloe vera leaves in their diets. Use of Aloe vera leaves should be encouraged as it helps to improve nutritional status and could be easily included in diet.

\section{Acknowledgements}

We are thankful to the Department of Agronomy, Punjab Agricultural University, Ludhiana for providing Aloe vera plants at free of cost for research purpose.

\section{References}

[1] Perez, J.A.M., Garcia, F.C., Palacios, S. and Perez, M. (2009) Epidemiology of Risk Factors and Symptoms Associated with Menopause in Spanish Women. Maturitas, 62, 30-36. http://dx.doi.org/10.1016/j.maturitas.2008.10.003

[2] Moilanen, J., Aalto, A.M., Hemminki, E., Aro, A.R., Raitanen, J. and Luoto, R. (2010) Prevalence of Menopause Symptoms and Their Association with Lifestyle among Finish Middle-Aged Women. Maturitas, 67, 368-374. http://dx.doi.org/10.1016/j.maturitas.2010.08.007

[3] Nappi, R.E. and Kierepa, M.K. (2010) Women's Voices in the Menopause: Results from an International Survey on Vaginal Atrophy. Maturitas, 67, 233-238. http://dx.doi.org/10.1016/j.maturitas.2010.08.001

[4] Surjushe, A., Vasani, R. and Saple, D.G. (2008) Aloe Vera: A Short Review. Indian Journal of Dermatology, 53, 163166. http://dx.doi.org/10.4103/0019-5154.44785

[5] Vinson, J.A., Al Kharrat, H. and Andreoli, L. (2005) Effect of Aloe Vera Preparations on the Human Bioavailability of Vitamins C and E. Phytomedicine, 12, 760-765. http://dx.doi.org/10.1016/j.phymed.2003.12.013

[6] Shelton, M.S. (1991) Aloe Vera, Its Chemical and Therapeutic Properties. International Journal of Dermatology, 30, 679-683. http://dx.doi.org/10.1111/j.1365-4362.1991.tb02607.x

[7] Wu, J.H., Xu, C., Shan, C.Y. and Tan, R.X. (2006) Antioxidant Properties and Pc12 Cell Protective Effects of Aps-1, a 
Polysaccharide from Aloe vera Var. chinensis. Life Sciences, 78, 622-630. http://dx.doi.org/10.1016/j.lfs.2005.05.097

[8] Hu, Q., Hu, Y. and Xu, J. (2005) Free Radical-Scavenging Activity of Aloe vera (Aloe Barbadensis Miller) Extracts by Supercritical Carbon Dioxide Extraction. Food Chemistry, 91, 85-90. http://dx.doi.org/10.1016/j.foodchem.2004.05.052

[9] Jelliffe, D.B. (1996) The Assessment of Nutrition Status of the Community. World Health Organization Monograph Series No. 53, Geneva, 50-84.

[10] Maclead, L. and (1984) Davidsons Principles and Practice of Medicine. 14th Edition, ELBS, Churchill Livingstone.

[11] ICMR (2011) Dietary Guidelines for Indians. A Manual of National Institute of Nutrition, Indian Council of Medical Research, Hyderabad.

[12] Sandhu, N., Sangha, J. and Sachdeva, R. (2005) Efficacy of Nutrition Intervention on the Anthropometric and Blood Profile of at Risk Coronary Heart Disease Subjects. Journal of Research, 42, 98-103.

[13] Ghafoorunissa and Krishnamurthy (2005) Diet and Heart Diseases. National Institute of Nutrition, Hyderabad.

[14] Kushwaha, S. (2011) Impact of Supplementation of Drumstick (Moringa oleifera) and Amaranth (Amaranthus tricolor) Leaves of Antioxidant Status of Postmenopausal Women. Master's Thesis, Punjab Agricultural University, Ludhiana.

[15] Chandla, S. (2006) Nutritional Profile of Vegetarian and Non Vegetarian Postmenopausal Women. Master's Thesis, Punjab Agricultural University, Ludhiana.

[16] ICMR (2010) Nutrient Requirements and Recommended Dietary Allowance for Indians. A Report of the Expert Group of the Indian Council of Medical Research, New Delhi.

[17] Jain, S. (2009) Impact of Dietary Intake and Calcium Supplementation on Bone Mineral Density as an Indicator of Osteoporosis in Menopausal Women. Master's Thesis, Punjab Agricultural University, Ludhiana.

[18] Kaur, G. (2007) Assessment of Nutritional and Health Profile of Premenopausal and Postmenopausal Women. Master's Thesis, Punjab Agricultural University, Ludhiana.

[19] ICMR (2003) Dietary Guidelines for Indians. A Manual of National Institute of Nutrition, Hyderabad.

[20] Choudhary, M. (2010) Hypoglycemic and Hypolipidemic Effect of Aloe vera L. in Non-Insulin Dependent Diabetics. Master's Thesis, Punjab Agricultural University, Ludhiana.

[21] WHO (1995) World Health Statistics Annual. Geneva.

[22] Jain, A. and Singh, N. (2003) A Study on Nutritional Status of Women in Age Group of 25 - 50 Years Working on Sedentary Job in Jaipur City. International Journal of Nutrition and Dietetics, 40, 91-98.

[23] Ghafoorunissa and Krishnamurthy (2007) Fatty Acid Composition of Food Items. Diet and Heart Diseases, 32-40.

[24] Srilakshmi, B. (2011) Dietetics. 6th Edition, New Age International Publisher, New Delhi, 313.

[25] Tanaka, M., Misawa, E., Ito, Y., Habara, N., Nomaguchi, K., Yamada, M., Toida, T., Hayasawa Hm Takase, M. and Higuchi, I.R. (2006) Identification of Five Phytosterols from Aloe vera Gel as Antidiabetic Compounds. Biological and Pharmaceutical Bulletin, 29, 418-422. http://dx.doi.org/10.1248/bpb.29.1418

[26] Raghuram, T.C., Pasricha, S. and Sharma, R.D. (2007) Diet and Diabetes. ICMR, Hyderabad. 